\title{
EFEKTIFITAS PIJAT BAYI TERHADAP PERTUMBUHAN DAN PERKEMBANGAN PADA BAYI USIA 5-6 BULAN DI DESA RANGKASBITUNG BARAT TAHUN 2017
}

\author{
Yayah Rokayah $^{1}$ dan Lisa Nurlatifah ${ }^{1}$ \\ ${ }^{1}$ Jurusan Kebidanan Poltekkes Kemenkes Banten \\ Korespondensi: yah_chikal@yahoo.co.id
}

\begin{abstract}
ABSTRAK
Anak memiliki nilai yang sangat tinggi untuk keluarga dan bangsa. Setiap orang tua mengharapkan anaknya dapat tumbuh dan berkembang secara optimal, sehingga dapat menjadi sumber daya manusia yang berkualitas dan tangguh. Tercapainya pertumbuhan dan perkembangan yang optimal merupakan hasil interaksi berbagai faktor yang saling berkaitan, yaitu faktor genetika, lingkungan, perilaku dan rangsangan atau stimulus yang berguna (Dasuki, 2003). Jenis penelitian yang digunakan adalah quasi eksperimen dengan pendekatan non randomize pretest-posttest with control gruoup desaign. Penelitian ini dilakukan dengan cara memberikan pelatihan pijat bayi pada ibu atau keluarga untuk selajutnya dilakukan pijat bayi secara rutin dan dilakukan pemantauan berkala oleh peneliti. Penilaian tumbuh kembang dilakukan sebelum dan sesudah diberikan pijat bayi dengan pembanding bayi yang tidak diberikan pijat bayi. Instrument yang digunakan adalah panduan pijat bayi bagi ibu dan lembar pemantauan tumbuh kembang bayi. Hasil penelitian menunjukan bahwa secara deskriptif rata-rata peningkatan pertumbuhan (berat badan dan panjang badan) serta kemajuan perkembangan (motorik kasar, bahasa, motorik halus, dan sosial) lebih tinggi pada kelompok intervensi dibandingkan dengan kelompok kontrol. Hasil uji statistik didapatkan nilai $(\mathrm{p}=0,01)$ maka dapat dikatakan bahwa tindakan pijat bayi memberikan dampak positif terhadap peningkatan berat badan, sedangkan pada variabel panjang badan $(\mathrm{p}=0,22)$, motorik kasar $(0,37)$, bahasa $(0,61)$, motorik halus $(0,66)$ dan bahasa $(0,66)$ sehingga tidak ada hubungan yang signifikan antara pijat bayi dengan variabel tersebut.
\end{abstract}

Kata Kunci: Pijat Bayi, Tumbuh dan Kembang Bayi usia 5-6 bulan.

\section{PENDAHULUAN}

Anak memiliki nilai yang sangat tinggi untuk keluarga dan bangsa. Setiap orang tua mengharapkan anaknya dapat tumbuh dan berkembang secara optimal, sehingga dapat menjadi sumber daya manusia yang berkualitas dan tangguh.Tercapainya pertumbuhan dan perkembangan yang optimal 
merupakan hasil interaksi berbagai faktor yang saling berkaitan, yaitu faktor genetika, lingkungan, perilaku dan rangsangan atau stimulus yang berguna (Dasuki, 2003).

Masa bayi disebut juga periode vital, karena kondisi fisik dan mental bayi menjadi pondasi yang kokoh bagi pertumbuhan dan perkembangan selanjutnya. Bayi baru lahir yang sehat dengan cepat akan menyesuaikan diri dengan alam lingkungannya dan melakukan tugas-tugas perkembangan tertentu.

Masa bayi dikatakan pula sebagai golden age atau masa keemasankarena pada masa ini perkembangan otak berlangsung.Otak bayi memiliki sifat plastis yaitu kemampuan susunan syaraf untuk menyesuaikan diri terhadap perubahan dan kerusakan yang disebabkan oleh faktor eksternal dan internal, penyesuaian kemampuan syaraf untuk regenerasi (Zero to Three, 2012).

Pada setiap tahap perkembangan, terdapat beberapa aspek fisik dan psikologis yang terjadi, misalnya pada masa bayi secara umum menunjukkan bahwa anak sangat tergantung pada orang dewasa, sedangkan saat anak memasuki awal masa kanak-kanak, ketergantungan mulai berkurang dan ada harapan serta perlakuan tertentu dari kelompok sosial serta mulai tumbuh kemandirian, yang akan berakhir saat anak mulai masuk sekolah dasar. Perkembangan pada setiap aspek memiliki tingkat dan kecepatan yang berbeda-beda baik, tergantung dari faktor individu maupun lingkungan yang menstimulirnya. Seluruh perkembangan ini akan dilampaui anak dan setiap aspek perkembangannya tidak berdiri sendiri melainkan saling terkait satu sama lain.

Pertumbuhan terjadi secara simultan dengan perkembangan. Pertumbuhan adalah bertambahnya ukuran dan jumlah sel serta jaringan interselular. Berarti bertambahnya ukuran fisik dan struktur tubuh sebagain atau keseluruhan, sehingga dapat diukur dengan satuan panjang dan berat. Sedangkan perkembangan adalah bertambahnya struktur dan fungsi tubuh yang lebih kompleks dalam kemampuan gerak kasar, gerak halus, bicara dan bahasa, serta sosialisai dan kemandirian.Berbeda 
dengan pertumbuhan, perkembangan merupakan hasil interaksi kematangan susunan saraf pusat dengan organ yang dipengaruhinya.

Ikatan batin yang sehat (secure attachment) sangat penting bagi anak terutama dalam usia 2 tahun pertama yang akan menentukan perkembangan kepribadian anak selanjutnya. Selain faktor bawaan yang dianugerahkan Tuhan sejak lahir, stimulus dari luar juga berperan bagi pertumbuhan fisik dan perkembangan emosional anak (Prasetyono, 2009).

Stimulasi sentuh dapat merangsang semua sensorik dan motorik yang berguna untuk pertumbuhan otak, membentuk kecerdasan emosi, inter, intrapersonal dan untuk merangsang kecerdasankecerdasan lain. Anak yang mendapat stimulasi yang terarah dan teratur akan lebih cepat berkembang dibandingkan dengan anak yang kurang/ tidak mendapat stimulasi (Soedjiningsih, 2009).

Keputusan Menteri Kesehatan Nomor 900/MENKES/SK/VII/2002 tentang Registrasi dan Praktik Bidan menyebutkan bahwa bidan berwewenang memantau tubuh kembang bayi melalui deteksi dini dan stimulasi tumbuh kembang. Salah satu bentuk stimulasi yang selama ini dilakukan oleh masyarakat adalah dengan pijat bayi (Prasetyono, 2009).

Menurut Roesli, pijat bayi adalah terapi sentuh tertua dan terpopuler yang dikenal manusia. Pijat bayi telah lama dilakukan hampir di seluruh dunia, termasuk Indonesia dan diwariskan secara turun temurun (Prasetyono, 2009).

Pijat bayi adalah mengurut bagian tubuh bayi untuk melemaskan otot sehingga peredaran darah lancar.Sentuhan dan pijatan pada bayi setelah kelahiran dapat memberikan jaminan adanya kontak tubuh berkelanjutan yang dapat meberikan perasaan aman pada bayi. Sentuhan juga akan merangsang peredaran darah dan menambah energy karena gelombang oksigen yang segar akan lebih banyak dikirim ke otak dan seluruh tubuh.

Pijat bayi sangat penting bagi kesehatan bayi.Terutama apabila dilakukan oleh orang tuanya sendiri.Sehingga peran orang tua sangat dibutuhkan dalam memberikan pijatan pada bayi.Agar menciptakan 
komunikasi antara orang tua dan bayi melalui sentuhan pijatan yang mengandung unsur kasih sayang, suara, kontak mata dan gerakan.Pijat pada bayi dapat melibatkan keluargakeluarga terdekat untuk mendekatkan hubungan emosional, misalnya ayah, nenek, kakek.Naluri seorang bayi dapat merespon sentuhan dari ibunya sebagai ungkapan rasa cinta, perlindungan dan perhatian (Roesli, 2013).

Banyak penelitian menunjukan bahwa pemijatan pada bayi memberikan manfaat sangat besar pada perkembangan bayi, baik secara fisik maupun secara emosional. Pijat bayi akan merangsang peningkatan aktifitas syaraf nervus vagus yang akan menyebabkan penyerapan lebih baik pada system percernaan sehingga bayi akan lebih cepat lapar dan ASI akan lebih baik diproduksi.

Penelitian terkait dengan pijat bayi antara lain, penelitian oleh Jin Jing et al (2007) mendapatkan hasil bahwa pada bayi yang diberikan perlakuan pijat bayi dan latihan gerak, pertumbuhan dan perkembangan lebih cepat dibandingkan dengan bayi yang tidak diberikan pijat dan latihan gerak.
Selain itu penelitian oleh Puspita Eka Kurnia Sari (2014) didapatkan bahwa nilai efektifitas pijat bayi terhadap pertumbuhan dan perkembangan bayi umur 6 bulan dihitung dari hasil odds ratio didapatkan pijat bayi 11 kali lebih besar untuk mengangkat dada dan 10 kali lebih besar untuk mengangkat leher.Nilai efektifitas pijat bayi terhadap pertumbuhan (berat badan dan panjang badan bayi) dihitung dengan menggunakan rumus eta squared diperoleh hasil 0,28 untuk berat badan bayi dan 0,43 untuk panjang badan bayi.

Studi pendahuluan yang dilakukan oleh peneliti melalui sampel 10 bayi yang berusia 5-6 bulan pada bulan April Tahun 2017 di desa Rangkasbitung Barat untuk dilakukan pemantauan Stimulasi Deteksi dan Intervensi Dini Tumbuh Kembang (SDIDTK) menggunakan buku KIA, didapatkan hasil sebanyak 3 orang bayi yang mengalami keterlambatan pada perkembangannya.

Bayi yang menjadi sampel dalam studi pendahuluan telah dipastikan dalam keadaan sehat secara fisik, tidak mengalami gizi buruk, tidak kegemukan, tidak pernah 
mengalami kejang demam dan terlahir dengan kondisi yang sempurna secara fisik.

Dari hasil wawancara yang dilakukan pada orang tua bayi yang dijadikan sampel studi pendahuluan, ibu mengatakan bahwa bayi akan tumbuh optimal hanya dengan diberi ASI dan makanan tambahan, ibu belum mengetahui tentang pijat bayi dan manfaatnya terhadap tumbuh kembang bayi.

Dari latar belakang tersebut, peneliti merasa tertarik untuk melakukan penelitian tentang efektifitas pijat bayi terhadap pertumbuhan dan perkembangan pada bayi usia 5-6 bulan di Desa Rangkasbitung Barat Kecamatan Rangkasbitung tahun 2017.

\section{METODE}

Penelitian ini merupakan penelitian kuantitatif dengan desain quasi eksperiment, yaitu memberikan perlakuan atau intervensi pada kelompk eksperimen dan kemudian efek dari perlakuan tersebut diukur dan dianalisis (Polit \& Hungler, 2006). Pendekatan penelitian ini denganone grup pre test-post test design untuk mengetahui efektifitas dari pijat bayi terhadap pertumbuhan dan perkembangan bayi usia 5-6 bulan sebelum dan sesudah diberikan perlakuan pijat bayi selama satu bulan.

Pada penelitian ini pengambilan sampelnya dengan menggunakan total sampling, yaitu teknik penentuan sampel dengan mengambil seluruh anggota populasi sebagai responden atau sampel penelitian.(Sugiyono, 2009).

Populasi dalam penelitian ini adalah seluruh bayi (usia 5-6 bulan) di Desa Rangkasbitung Barat sejumlah 20 orang bayi. Sampel penelitian ini adalah total polulasi, 10 orang bayi dijadikan kelompok intervensi dan 10 orang bayi lainnya dijadikan kelompok kontrol. Penelitian ini dilakukan pada bulan Juni sampai dengan Desember 2017.

Jenis data yang dikumpulkan dalam penelitian ini adalah data primer. Pengumpulan data dilakukan dengan cara pengukuran dan penilaian pertumbuhan dan perkembangan bayi dengan menggunakan instrument lembar identitas responden, timbangan bayi, pengukur panjang badan bayi, lembar DDST untuk menilai 
perkembangan anak usia 5-6 bulan. Serta pedoman pijat bayi untuk orang tua bayi. Peneliti juga mendemostrasikan langkah-langkah pijat bayi serta memutarkan video pijat bayi sebagai tambahan pengetahuan untuk orang tua bayi.

Data diolah dengan menggunakan bantuan Komputer. Tahap pertama dilakukan analisis univariat untuk melihat frekuensi dan presentase, selanjutnya analisis bivariat untuk melihat pengaruh variabel bebas terhadap variabel terikat.

\section{HASIL}

1. Univariat
a. Rerata Peningkatan berat Badan dan Panjang Badan

Secara deskriptif rata-rata peningkatan pertumbuhan (pada berat badan dan panjang badan) dapat di simpulkan bahwa rerata peningkatan panjang badan pada kelompok intervensi lebih besar yaitu sebanyak 533 gr di bandingkan pada kelompok control yaitu 360 gr, dan untuk rerata pertambahan panjang badan pada kelompok intervensi lebih tinggi yaitu $1,06 \mathrm{~cm}$ dibandingkan pada kelompok control yaitu $0.70 \mathrm{~cm}$
b. Rerata Peningkatan Perkembangan.

Secara deskriptif rerata peningkatan perkembangan pada motoric kasar pada kelompok intervensi lebih tinggi yaitu 1,67 di bandingkan kelopok control yaitu 1.50, untuk motoric halus rerata peningkatan perkembangan lebih tinggi pada kelompok intervensi yaitu $0,56 \mathrm{di}$ bandingkan kelompok control yaitu 0.40, selanjutnya untuk rerata perkembangan bahasa terjadi peningkatan lebih tinggi pada kelompok intervensi yaitu 0.33 di bandingkan kelompok kontrol yaitu 0.21 dan untuk rerata perkembangan pada social lebih tinggi pada kelompok intervensi yaitu 0.56 di bandingkan pada kelompok Kontrol. 
2. Bivariat

Tabel I

Data Hasil Pengukuran Pertumbuhan dan Perkembangan Bayi pada Kelompok Intervensi dan Kelompok Kontrol

\begin{tabular}{|c|c|}
\hline & \\
\hline $\begin{array}{l}\Delta \text { Berat } \\
\text { Badan }\end{array}$ & $\begin{array}{c}\Delta \\
\text { Motorik } \\
\text { Halus }\end{array}$ \\
\hline $533 \mathrm{gr}$ & 0,56 \\
\hline $360 \mathrm{gr}$ & 0,40 \\
\hline$* * 0,01$ & $* 0,66$ \\
\hline $\begin{array}{l}\text { Keterangan : ** Uji T } \\
\text { * Uji Mann-Whitney } \\
\text { a. Pertumbuhan ( } \mathrm{BB} \text { dan Panjang } \\
\text { Badan) } \\
\text { Hasil uji statistik terdapat } \\
\text { distribusi data yang normal pada } \\
\text { variabel berat badan sehingga } \\
\text { dilakukan uji beda menggunakan } \\
\text { uji T. Dari hasil uji tersebut } \\
\text { didapatkan nilai yang bermakna } \\
\text { antara peningkatan berat badan } \\
\text { pada kelompok intervensi } \\
\text { dibandingkan dengan kelompok } \\
\text { kontrol (p=0.01). Namun untuk } \\
\text { hasil uji statistic variable panjang } \\
\text { badan didapatkan distribusi data } \\
\text { yang tidak normal sehinggan } \\
\text { dilakukan uji beda menggunakan }\end{array}$ & $\begin{array}{l}\text { Man whitney. Dari hasil uji tersebut } \\
\text { didapatkan nilai yang tidak } \\
\text { bermakna pada peningkatan } \\
\text { panjang badan baik pada kelompok } \\
\text { intervensi maupun kelompok } \\
\text { control. (0,22). } \\
\text { Perkembangan } \\
\text { Hasil uji statistik pada variabel } \\
\text { motori kasar, bahasa, motorik halus } \\
\text { dan sosial terdapat distribusi data } \\
\text { yang tidak normal sehingga } \\
\text { dilakukan uji mann-whitney. Dari } \\
\text { hasil uji tersebut did apatkan } \\
\text { seluruh variable tidak bermakna } \\
\text { karena melebihi nilai a } 0,05 \text { yaitu } \\
\text { pada variabel motoric kasar (0,37), }\end{array}$ \\
\hline
\end{tabular}


bahasa $(0,61)$, motorik halus $(0,66)$ dan sosial $(0,66)$.

\section{PEMBAHASAN}

1. Pertumbuhan

Dari hasil uji statistik pijat bayi terhadap peningkatan BB didapatkan nilai $P$ value $(0,01)$ dengan demikian dapat dikatakan bahwa tindakan pijat bayi pada kelompok intervensi terjadi peningkatkan berat badan yang signifikan dibandingkan pada kelompok kontrol, hal ini disebabkan karena dengan pemberian pijat pada bayi minimal sehari satu kali dapat merangsang nervus vagus yang akan merangsang peristaltik usus, sehingga akan mempercepat pengosongan lambung, dengan demikian akan merangsang nafsu makan bayi dan bayi akan cepat merasa lapar.

Pernyataan ini sesuai dengan hasil penelitian Umi kulsum tahun (2014) yang menyatakan bahwa bayi yang dipijat atau di massage rutin akan terjadi peningkatan berat badan sebanyak $4,11 \%$ dibandingkan dengan bayi yang tidak dilakukan pemijatan. Dan menurut teori Ardiana. D (2013) mengatakan bahwa bayi yang mendapat ransangan melalui sentuhan atau pijat bayi akan mengalami tonus nervus vagus (saraf otak ke 10) pijatan tersebut dapat merangsang peningkatan kadar enzim penyerapan gastrin dan insulin yang bisa meningkatkan BB.

Selanjutnya hasil uji statistik pijat bayi terhadap peningkatan panjang badan didapatkan nilai $P$ value (0.22) dengan demikian tidak ada pengaruh yang signifikan pijat bayi terhadap peningkatan panjang badan pada kelompok intervensi maupun kelompok kontrol.

Berdasarkan hasil deskriptif didapatkan terjadi peningkatan panjang badan lebih besar pada kelompok intervensi yaitu (1,06 $\mathrm{cm})$ dibandingkan dengan kelompok control $(0,70 \mathrm{~cm})$ hal ini membuktikan bahwa ada hasil positif dari pijat bayi yang dilakukan setiap hari selama satu bulan. Namun demikian ada factor lain yang bisa mempengaruhi pertumbuhan pada bayi atau anak 
salah satunya adalah perawatan selama kehamilan, perawatan setelah lahir, pemberian gizi dan pengaruh lingkungan dan social budaya dari keluarga tersebut. Hal ini sesuai dengan teori Nursalam (2015) yang menyatakan bahwa pertumbuhan dan perkembangan yang maksimal pada anak akan dipengaruhi oleh beberapa factor diantaranya factor prenatal (gizi waktu hamil, obat-obatan, penyakit ibu waktu hamil) dan postnatal (gizi anak, kesehatan anak, sanitasi dan stimulasi).

\section{Perkembangan}

a. Motorik Kasar

Dari hasil evaluasi pijat bayi yang dilakukan selama 1 bulan pada kelompok control terjadi peningkatan perkembangan pada motoric kasar , hal ini karena dengan adanya rangsangan melalui sentuhan kulit/pijat ringan pada bayi yang baik akan merangsang saraf otak untuk mengendalikan aktifitas motoric sehingga mampu meningkatkan perkembangan pada motoric kasar.

Hal ini sesuai dengan penelitian yang dilakukan oleh Raras N (2015) yang menyatakan bahwa bayi akan mengalami perkembangan yang baik jika mendapatkan rangsangn pada kulit yang akan memberi efek nyaman dan akan meningkatkan perkembangan. Namun secara uji statistik pijat bayi terhadap perkembangan bayi dari motorik kasar didapatkan nilai $P$ value 0.66 ini menunjukan tidak ada perbedaan yang bermakna pijat bayi terhadap perkembangan motoric kasar, karena ada factor lainyang bia mempengaruhi perkembangan yaitu Gizi, perawatan selama kehamilan dan post natal serta social ekonomi.

b. Motorik Halus

Dari hasil evaluasi pijat bayi yang dilakukan selama 1 bulan pada kelompok control terjadi peningkatan perkembangan pada motoric halus , hal ini karena dengan adanya rangsangan melalui sentuhan kulit/pijat ringan pada bayi yang baik akan merangsang saraf otak untuk mengendalikan aktifitas motoric sehingga mampu meningkatkan perkembangan pada motoric. Hal ini tidak sesuai dengan penelitian yang dilakukan oleh Raras N (2015) yang menyatakan bahwa bayi akan mengalami perkembangan yang baik 
jika mendapatkan rangsangn pada kulit yang akan memberi efek ynyaman dan akan meningkatkan perkembangan. Namun secara uji statistik pijat bayi terhadap perkembangan bayi dari motorik kasar didapatkan nilai $P$ value 0.37 ini menunjukan tidak ada perbedaan yang bermakna pijat bayi terhadap perkembangan motoric kasar, karena ada faktor lain yang bisa mempengaruhi perkembangan yaitu Gizi, perawatan selama kehamilan dan post natal serta social ekonomi.

c. Bahasa

Dari hasil evaluasi pijat bayi yang dilakukan selama 1 bulan pada kelompok intervensi terjadi peningkatan perkembangan social dibandingkan pada kelompok kontrol, hal ini karena rangsangan melalui sentuhan kulit/pijat ringan yang dilakukan oleh ibu pada bayinya akan membentuk jalinan kasih sayang atau bounding Attachman antara ibu dan bayi yang akan memberikan efek nyaman sehingga bayi mudah untuk bersosialisasi dengan lingkungan sekitarnya, dengan demikian bisa meningkatkan pada perkembangan social bayi. Namun hasil uji statistic menunjukan nilai $P$ Value 0,61 sehingga tidak ada perbedaan yang bermakna pijat bayi terhadap perkembangan social bayi hal ini terjadi karena ada factor lain yang mempengaruhi yaitu perawatan prenatal, perawatan pasca natal, lingkungan, social budaya dan stimulus. Pernyataan ini sesuai dengan teori Soetjiningsih (1999) dan Nursalam (2015) menyatakan bahwa beberapa factor diantaranya factor prenatal ( gizi waktu hamil, obatobatan, penyakit ibu waktu hamil) dan postnatal (Gizi anak, kesehatan anak, sanitasi dan stimulasi) factor lainnya . Namun penelitian ini tidak sesuai dengan hasil penelitian Vera.V (2014) yang menyatakan bahwa ada pengaruh yang signifikan pijat bayi terhadap perkembangan bayi pada kelompok intervensi dibandingkan dengan kelompok control yang tidak di pijat dengan nilai $P$ Value $(0.000)$.

\section{d. Sosial}

Dari hasil evaluasi pijat bayi yang dilakukan selama 1 bulan pada kelompok intervensi terjadi peningkatan perkembangan social dibandingkan pada kelompok kontrol, hal ini karena rangsangan melalui 
sentuhan kulit/pijat ringan yang dilakukan oleh ibu pada bayinya akan membentuk jalinan kasih sayang atau bounding Attachman antara ibu dan bayi yang akan memberikan efek nyaman sehingga bayi mudah untuk bersosialisasi dengan lingkungan sekitarnya, dengan demikian bisa meningkatkan pada perkembangan social bayi. Namun hasil uji statistic menunjukan nilai $P$ Value 0,66 sehingga tidak ada perbedaan yang bermakna pijat bayi terhadap perkembangan social bayi hal ini terjadi karena ada factor lain yang mempengaruhi yaitu perawatan prenatal, perawatan pasca natal, lingkungan, social budaya dan stimulus. Pernyataan ini sesuai dengan teori Soetjiningsih (1999) dan Nursalam (2015) menyatakan bahwa beberapa factor diantaranya factor prenatal ( gizi waktu hamil, obatobatan, penyakit ibu waktu hamil) dan postnatal (Gizi anak, kesehatan anak, sanitasi dan stimulasi) factor lainnya . Namun penelitian ini tidak sesuai dengan hasil penelitian Vera.V (2014) yang menyatakan bahwa ada pengaruh yang signifikan pijat bayi terhadap perkembangan bayi pada kelompok intervensi dibandingkan dengan kelompok control yang tidak di pijat dengan nilai $P$ Value (0.000).

\section{SIMPULAN}

Pijat bayi memberikan efek yang signifikan terhadap peningkatan berat badan bayi. Namun tidak signifikan pada pertambahan panjang badan bayi dan perkembangan bayi (motorik kasar, motorik halus, bahasa dan sosial).

Saran untuk tenaga kesehatan agar mensosialisasikan kepada kader kesehatan dan masyarakat tentang pentingnya pijat bayi untuk mendukung pertumbuhan dan perkembangan anak.

\section{DAFTAR PUSTAKA}

Arikunto, S. 2002. Prosedur Penelitian. Jakarta : Rineka Cipta

Fitriani, L \& Nurhidayati, N. 2007. Pengaruh Pijat Bayi terhadap Peningkatan Nafsu Makan Bayi Usia diatas 6 Bulan di Poli Klinik Fisioterapi Handicamp International Wedi Klaten. Semarang: UNS

Hastono, S. P. \& Sabri, L. 2010. Statistik Kesehatan. Jakarta : Rajawali Pers

Health, A \& Bainbridge, N. 2004. Baby Massage : The Calming 
Power of Touch. New York : DK Publishing, Inc

Hidayat, A. A. 2012. Metode Penelitian Kebidanan \& Teknik Analisis Data. Jakarta : Salemba Medika

Kurnia S., Puspita E. 2014. Efektifitas Pijat Bayi terhadap Pertumbuhan dan perkembangan Bayi usia 6 bulan di Kelurahan Bintaro Jakarta. Skripsi UIN

Marimbi, H. 2010. Tumbuh Kembang, Status Gizi, dan Imunisasi Dasar pada Bayi. Jogjakarta : Nuha Medika

Notoadmojo, S. 2010. Metodologi Penelitian Kesehatan. Jakarta : Rineka Cipta.

Nugrohowati, R. \& Nurhidayati, E. 2015. Pengaruh Pijat Bayi Terhadap Tumbuh Kembang Bayi usia 0-12 Bulan di Desa Margodadi Kecamatan Seyegan Kabupaten Sleman. Skripsi STIKES Aisyiyah Yogja

Nursalam, S. U. 2008. Asuhan Keperawatan Bayi dan Anak (untuk Perawat dan Bidan). Jakarta : Salemba Medika

Prasetyono. 2009. Teknik-teknik Tepat Memijat Bayi Sendiri. Jogjakarta : DIVA Press

Roesli, U., 2001. Pedoman Pijat Bayi. Trubus Agriwidya, Jakarta.

Roesli, U., 2001. Pedoman Pijat Bayi Prematur dan Bayi Usia 0-3 Bulan. Trubus Agriwidya, Jakarta.

Saryono. 2011. Metodologi Penelitian Kesehatan.Jogjakarta : Mitra Cendikia Press

Soedjiningsih. 2009. Tumbuh Kembang Anak. Jakarta : EGC 